viajam ou pretendem viajar decidem fazê-lo somente em função da propaganda, ou seja, constata que o papel das pessoas que recomendam é decisivo ao turista.

A Segunda Parie - Aspectos da Comunicação Pliblicitária e Promocional no Marketing Turístico em Săo Paulo - composta de um capítulo, apresenta o trabalho de investigação realizado com publicitários, agenciadores de turismo e turistas. Muitos dados são autênticas revelaçōes para uma nova con uta e forma de se planejar o turismo brasileiro; um exemplo é que cerca de 2/3 dos operadores e agenciadores de turismo não realizam ou adquirem pesquisas de mercado, dado que equivale dizer que não conhecem seu mercado ou sua demanda; outro dado é que quase $90 \%$ desses profissionais agem isoladamente, ao invés de fazerem ações coletivas que poderiam resultar numa racionalização de custos.

Ao final do livro a autora apresenta dois Apêndices. No primeiro propõe um Modelo de Plano de Divulgação de Produtos Turísticos, valendo-se da definição de produto, mercado, concorrência, decisões de marketing, divulgação, atividades promocionais e controle da eficácia. No segundo destaca um tema atual e polêmico: Credibilidade das Mensagens Publicitárias do Turismo ressaltando que, cerca da metade dos entrevistados consideram que a propaganda turística não reflete a realidade encontrada pelo turista, fato este que obriga os profissionais do setor a criar um código de ética, uma vez que a credibilidade do setor $e$ insumo básico para sua eficiência; a aplicação do Código de Defesa do Consumidor, a partir de 1991, no Turismo, poderá beneficiar tanto o turista quanto o setor turístico como um todo, o qual, abandonando soluções amadorísticas, terá condições de estruturar-se sobre bases sólidas e mais profissionais.

\section{Em Busca de Novo Modelo para Atividades Turísticas}

Américo Pellegrini Filho

KRIPPENDORF, Jost. Sociologia do turismo. Rio de Janeiro, Civilização Brasileira, 1989; trad. por Contexto Trad. Ltda.

Um estudo crítico do comportamento do turista e de empresários do turismo - é como se pode sintetizar este livro de Jost Krippen- dort. Fugindo ao estilo encomiástico, o autor aponta com firmeza determinados vícios da atividade profissional em turismo, que funcionam como lamentáveis fatores de reafirmação da imagem negativa na sociedade: o turismo predador.

O livro (originalmente publicado em alemão, 1984, e depois em francês, 1987) compōe-se de quatro capítulos, cada um com diversos itens, dispostos em 236 páginas.

Nas páginas iniciais, há uma panorâmica - sem preocupação de colocação dicacrônica -, objetivando explicar que o fenômeno do turismo, nos tempos atuais, resulta da procura de evasão conjugada com outras motivações, tais como salários mais elevados, tempo livre, veículos e infraestrutura de transporte favoráveis e, enfim, a própria indústria do lazer. "Se não existisse o turismo. cúmplice da evasão, seria necessário construir clínicas e sanatórios, onde o ser humano se recuperasse do cansaço do cotidiano" (p. 18), especialmente considerando-se as agitadas metrópoles da sociedade industrial. O capítulo 2 e uma análise de motivações para o turismo, no qual o leitor se depara com um confronto não percebido pelo leigo - e pelo próprio turista ou seja, o "viajante" que se movimenta à procura de atrativos e o "viajado" que é como o autor denomina o indivíduo que recebe o turista, portanto as populações de núcleos receptores. No capítulo 3 , Krippendorf levanta problemas da sociedade do trabalho em crise, do tempo livre, da sociedade de consumo. E finalmente no último capítulo são apresentadas teses para a humanização da viagem.

Embora baseado na experiência européia, Krippendorf até parece ter estudado a problemática no Brasil: prega o "turismo suave" para locais não adequados ao turismo de massa, chama a atenção para o perigo de se considerar o turismo como a panacéia universal, a necessidade de conciliarem interesses de viajantes e viajados, aconselha o turista a ser um consumidor crítico e não apenas aceitar passivamente o que lhe vendem as empresas do ramo, lembra a necessidade de treinar melhor o elemento humano responsável pelas atividades profissionais na área, a necessidade de reescalonamento de férias para evitar as concentraçōes humanas em busca de descontração etc. "O turismo só deve ser encorajado na medida em que proporcionar, à população hospedeira, uma vantagem de ordem econômica" (p. 186); "o turismo engole os terrenos, a natureza e o patrimônio cultural, torna-se um novo colonizador e destrói o meio ambiente" (p. 189) - são frases (não as únicas) que nos fazem lembrar problemas fundiários que prejudicam o caiçara paulista e fluminense, e que poderiam ter sido evitados, problemas de interferências em traços culturais, prejuízos para o Pantanal Matogrossense etc., evitáveis mediante uma esclarecida política turística e um controle rigoroso. Quando? 